\title{
Electoral Map Fixed by Law, as a Phenomena that Changes the Economy and Strongholds
}

\author{
Erindi Bejko \\ University of Tirana \\ University Aleksander Moisiu, Durres \\ Email: eri_bejko@yahoo.com
}

\section{Doi:10.5901/mjss.2017.v8n2p2671}

\begin{abstract}
After emerging from communist dictatorship, with the implementation of the new political system, our country came under a few phenomena. As unlearned in this field started step by step to create a new political culture, pluralistic and built models of voting behavior. After years 90' in everyday jargon of political discussion in Albania began to be used the stronghold, as a concept, in which showed the loyalty of the electorate in favor of one party. But over the years this process took shape choice of a phenomenon which became part of the scientific studies authenticated for representing fragments in certain parts of government either locally as well as centrally. Protracted situation of transition in Albania, forced international institutions to recommend the change of territorial configuration of the country. Political parties are often seen as actors who abuse their powerful position to extort bribes, providing members and followers with lucrative positions in public, or to channel public resources into the hands of party leaders and supporters. The main functions of political parties in modern democracies include mobilizing voters to support political agendas, selection of candidates for public office and the organization of election campaigns
\end{abstract}

Keywords: territorial reform, stronghold, economy, politics

\section{Introduction}

Territorial reforms must be released basing to two elements, European experience and the countries tradition. According to Bundgaard, U. \& K. Vrangbæk (2007) ${ }^{1}$ there are three models for the implementation of the local territorial reform:

1. Voluntary coupling model,

2. Law regulated administrative model,

3. Mixed model, where the voluntary coupling is followed by a compulsory law.

The first model, the voluntary coupling has the advantage of the residents' hearings about the community conditions and needs, but this model is very slow. The law regulated administrative model is very fast, but the strategy is criticized for the absence of democracy and may be faced by the controversy by the local units and citizens. The third, mixed model is used in 1960s in Denmark local territorial reform and actually is implemented in Latvia. This model is positive for the local needs, but at the same time the thread from the law coupling exists.

The political actors ate bothered always when these reforms occur, because mainly with these debates the territorial reform has impacts on parties and center-suburbs report (Baldersheim, H. \& L.E Rose, 2010a²).

The territorial division before the reforming 385 local units, was clear that didn't reflect the development of nowadays technology, but at the same time didn't respond the citizens needs whose expectations from local governance performance are increasing. Developed countries like Norway are in Albanian's phase, applying these reform supporting the idea of municipalities increasing size. Another developed country who is subject of the territorial reforms is Belgium where the main question was whether the reform would serve to the political parties or the citizens. The same question is valid also to Albania where the suspicions if the reform will serve to a specific political party are huge. Together with the

${ }^{1}$ Bundgaard, U. \& K. Vrangbæk Reform by coincidence? Explaining the policy process of structural reform in Denmark, Scandinavian Political Studies 30, 4, 491-520, 2007.

${ }^{2}$ Baldersheim, H. \& L.E Rose. Territorial choice: Rescaling Gvoernance in European states, 1-20m Baldersheim, H. \& L.E Rose (eds): Territorial choice: The politics of boundaries and borders. London: Palgrave macmillan, 2010a. 
common design elements, cases in Europe where similar places have applied different territory couplings, although the common history have applied different models since 1997, like in Poland and Ukraine cases. Poland is a success case, because has given more independence and democracy chances to local governance institutions and has created more economically and professionally powerful municipalities (Hulst, R. \& A.V. Montfort (2007). ${ }^{3}$

\subsection{Why Albania needs the territorial reform and which are the impacts?}

The territorial division of course will be accompanied by changes in politics and economy, because the rural and urban zones votes coupling may misbalance 24 years political strongholds and also cuts from the state's budget a considerable fund. Among the reasons that this reform occurs nowadays, the other countries positive experience, European Union's recommendations, USAID 2012, SIDA and UNDP (2005-2006) reports may be mentioned. The existing division was impossible to occur because the small governance units didn`t have the necessary human, professional and financial resources. Also the countries fragmentation - $20 \%$ of the Albanians population live in 232 units of the local governance or over $75 \%$ of the total units of the local governance have less than 5000 residents and as a result this has a very high cost in offering public service to the citizens. Limited human resources which the small administrative units face and as a result the disability to realize the local functions, the funds generation, collection and the services (Ministria e Ceshtjeve Vendore, Reforma Administrative-territoriale, 2014). ${ }^{4}$

A bigger municipality will be economically stronger and away from the social influences that occur in small zones for the taxes levy, will have a wide service range, lower costs, not fragmented budget and professionally better in financial politics implementation.

Also an economically stronger municipality would give to the citizens the opportunity to participate to projects, like participatory budgeting where the citizens have the chance to be part of the zones policy development politics (Ministria $\mathrm{e}$ Ceshtjeve Vendore, Reforma Administrative-territoriale, 2014).

The change of strongholds dynamics will be one of the study subjects of political scientists. According to this study, important municipalities may have changes in strongholds depended by the votes of the rural zones.

The change of political bastions dynamics will be one of the most studied points by the political scientists, because some municipalities may change side affected by the votes of the rural zones. The main aim of this study is the analysis of the real political and economical effects of the territorial reform.

The results of the study are focused on the citizens' benefits and the expected changes of the political map of the local government, which will be a prediction for the organization of the next electoral campaigns.

\subsection{Current situation}

Together with the pluralist system in Albania, huge migration and immigration movements occurred in Albania. Italy and Greece were the most preferred countries. Also, the inside migration was concentrated in Durres and Tirana by the north zone. According to the INSTAT 2011 study report, Albania's population, compared to that of a decade before has declined by $7.7 \%$ (Instat, 2011) ${ }^{5}$.

Also the number of the citizens that live in the city in report to the citizens that live in rural zones has increased. This tendency is noted in the first years of pluralism. According to the INSTAT study 'Urban and rural population in Albania in 1950-2050', the population in the rural zones in years 1990-1995, for the first time marked a downward swing, declining with $8.45 \%$, and the urban population increased with just $1.76 \%$. In the future projections, is noted an exodus from the rural zones and a dominance of the urban population. Beginning from the year 2010, the structure of the ruralurban population report became $50 \%-50 \%$. In 2020 , the report of the urban population is expected to be $60 \%$ of the total population and in 2035 this report will be over 70\% (Territorial reform in Albania, 2012) 6 .

The current territorial division dates in 1992, where Albania is selected to have 313 communes and 63 municipalities. Approximately 7950 citizens and $77 \mathrm{~m} 2$ for every local unit (Territorial reform in Albania, SKL International, 2012). Firstly the municipalities had incomplete competencies because of the communist mentality and the centralized power. With the strategy of the decentralization of the local government (Interior Ministry, 2010), the local government institutions gradually begun to take competencies like sewage of drinking water, building's facade, the right to demolition,

\footnotetext{
${ }^{3}$ Hulst, R. \& A.V. Montfort. Inter-municipal Cooperation in Europe. Dordrecht, Springer. 2007

${ }_{4}^{4}$ Ministria e Ceshtjeve Vendore, Reforma Administrative-territoriale, Raport i Pergjithshem, 2014

${ }^{5}$ Studimi demografik dhe shendetesor ne Shqiperi, Instat 2011

${ }^{6}$ Territorial reform in Albania, SKL International, 2012
} 
the right to have municipal police, museums administration, markets management, public transportation etc.

Self governance became a known concept after the approval of the European local self governance card. The implementation was really weak, because of the fact that the small units of the governance don't have enough human, economic and professional resources to have a successful self governance model. In 2013, the government had a focus on local governance like one of the sectors that was in need of a deep reform and created a proper ministry for this issue. Except the suggestions for the need of the territorial reform by the foreign organizations like PNUD or SIDA some suggestions come also by the majors of the local units institutions. This suggestions are documented in the 'Albanian territorial reform 'SIDA report (Ministria e Ceshtjeve te Pushtetit Vendor, Analize e Situates se Qeverisjes Vendore, 2014) $)^{7}$.

Promoted by the demographic movements, increasing role of the self governance, suggestions of foreign organizations, suggestions of the leaders of local government, in 31 July, 2014, after the consultations with the citizens, target groups, businesses etc, with 88 pro votes the Law for the territorial reform is adopted. This law is expected to have an impact in governance structure, funds allocation, human resources management and the self governance and decentralization process consolidation. This reform will change the administrative and political structure of the local government institutions in terms of tax policy, agricultural policy, rural zones representation in local councils, management of the water supply and sewerage, grants benefits from the state budget and different international projects, waste cleaning service, realignment of the roads, nurseries, kindergartens, supply with drinking water, social, education and health policies etc.

The territorial consolidation will make possible the delegation of more services to the local government, will have more capacity to have more administrative functions and will offer more opportunities to promote the local democracy. This territorial consolidation aims firstly the creation of the missing efficient economy and will make possible the bigger local government units to offer more effective low cost services (Ministria e Ceshtjeve te Pushtetit Vendor, Analize e Situates se Qeverisjes Vendore, 2014) ${ }^{8}$.

\section{Methodology}

The territorial reform is a new phenomenon. Because of this fact, the scientific data is really less. However, this study aims to highlight the changes of political balances and the economic benefits of the country related to the minimization of the costs of public administration. The data and the information related, is taken by the empirical database and the reports provided by the Ministry of Local Government, reports of the Central Election Commission and financial statistics in order to study the vote trend and the change of the strongholds dynamics. Also, the highlights of the savings and its impact to the votes balance will support to the compilation of the conclusion related to the effectiveness of this public policy.

\section{Discussion of the Results}

\subsection{The political effects expected by the territorial reform}

In order to understand the political effects of the territorial reform two second level municipalities will be studied, Kavaja and Pogradec city. Both cities have voted for the same party for four following local elections, respectively, Pogradec for the Socialist party and Kavaja for Democratic Party. There is no determined concept over the stronghold criteria. The criterion decided by the author is voting the same party over three times. Of course talking about the local elections, the candidate has a large role, but the aim of the study is to focus just on the poltical parties, not the candidates, and specifically the focus is on the results of the political parties, Democratic party (DP) and Socialist party (SP) in the last two local elections.

Pogradec is a local unit which with the territorial reform joins with 7 communes: Bucimas, Cerrave, Dardhas, Hudenisht, Proptisht, Trebinje, Velcan. The results of the city in report to the rural zones and the differences between two main parties mentioned above will be analyzed as below:

In the 2007 elections in Pogradec city, DP had 1995 comparing to 2967 votes of the SP. A difference of 872 votes is observed. The research question is whether there is a superiority of SP also in seven communes that are united to Pogradec city.

\footnotetext{
${ }^{7}$ Ministria e Ceshtjeve te Pushtetit Vendor, Analize e Situates se Qeverisjes Vendore, 2014

${ }^{8}$ Ministria e Ceshtjeve te Pushtetit Vendor, Analize e Situates se Qeverisjes Vendore, 2014 
In the voting centers of the seven communes that in 2015 will vote for Pogradec municipality, in 2007 local elections, DP had 2657 votes versus 2643 SP votes. The result shows that the seven communes coupling to Pogradec city there isn't any meaningful difference like the city's votes, bur DP is before with 14 votes. While, in this municipality versus 4862 votes of the urban zones there are 5300 votes of the rural zones. In the 2011 local elections, in Pogradec city, PD had 1912 votes versus 3729 votes of SP. This result showed that the stronghold is consolidated for the fourth time successively voted SP. From 872 differences in the votes of year 2007, in these elections SP leads with 1817 votes. In 7 communes coupling Pogradec municipality the result of 2011 elections is for DP 2859 votes versus 4501 SP votes. Clearly, in this elections, rural zones have followed the trend of the city's votes by having a difference of 1642 votes for SP. Also in these elections we have a superiority of rural zones voters (7360) versus urban zones (5641).

By this result, we conclude that if Pogradec city as a stronghold of Socialist Party, continues with this votes trend, doesn't lose regardless the coupling of 7 communes. But, the city's result is decided also by the villages vote, because in the last two elections, rural zones have a superiority of 438 voters in 2007 elections and 1719 voters in 2011 local elections.

Kavaja municipality, by 2015 will in custody 4 communes: Golem, Helmas, Synej, Luz. Kavaja is well known as right stronghold and as the only city that has voted for 5 times successively the same party, the Democratic Party. In the following paragraphs the rapport between the city's and the communes votes in the last two local elections will be analyzed.

In 2007 elections, in Kavaja city, DP had 2015 votes versus 364 votes of SP. The research question consists if DP will be in this superiority also in the four coupling communes to Kavaja.

In the election centers of the four communes that in 2015 will vote for Kavaja municipality, in 2007 local elections DP had 3435 versus 2396 votes of SP. The result shows that in the 4 coupling communes there are vote differences like in the city, because the DP is in superiority with 1039 votes. While, in this municipality versus 2379 votes of the urban zones there are 5851 votes of the rural zones, more than two times of the urban zones votes. In the 2011 local elections, in Kavaja city DP had 3351 votes versus 2874 votes of the SP. This result shows that the difference gets close from 1651 votes in 2007 to 477 votes, while the PS candidate wins the elections. In the four communes coupling to Kavaja city, the 2011 elections result is 3282 votes for DP versus 3208 votes of the SP. Clearly in these elections, rural zones lost the difference that characterizes stronghold zones by having 1039 votes' difference in 2007 to 74 in 2011 . Also in these elections we have a superiority of the rural zones voters (6490) versus 6224 urban zones voters.

According to these results we conclude that Kavaja city as a DP stronghold is declining in urban and rural zones, accordingly 3202 votes in 2007 and 265 votes in $2011^{9}$.

\subsection{The economic impacts of territorial reform}

To understand the financial effects that the territorial reform will have, we have a look on the efficiency of the public funds used by the local management units, on the level of the tax levy by these units and on the budget separation. As a result of fragmentation in Albania, 232 chairmen of the local government institutions that are 62 of the elected people, represent just $19 \%$ of the population. Also, in these units, there are 3000 advisors that also represent $19 \%$ of the population. While, there is a completely different situation for 18 majors and 620 advisors of the big zones, who represent $45 \%$ of the population. These disproportional divisions show that the current territorial division has channeled incomes to the zones where by the numeric view of the administrators are big, but by the population representation view are small. This shows that there is a lack of efficiency in the funds separation and allocation. With the new territorial reform these redundant salary costs will be eliminated for persons whose representative level is almost negligible.

Except the chairs and advisors salaries, more alarming is the situation in the rapport of the costs of the public funds among the investments and personnel salaries. Almost 70 units of local government, for 2012 didn't have any investment cost, while approximately local government units in Albania spend $27 \%$ of their budget for capital investments and $37 \%$ for personnel salaries. 40 local government units spend over $80 \%$ of their budget just for the personnel salaries, and 230 local government units (63\% of the local government units that represent $34 \%$ of the population) spend over $60 \%$ of their budget for personnel salaries. These administrative units don't make any investment, have finished their mission and are a burden for the public. Local government institutions must be institutions where the citizens' taxes must be translated to public services, not institutions where just some personnel must have a salary.

${ }^{9}$ Komisioni Qendror i Zgjedhjeve. www.cec.org 


\section{Conclusion}

Territorial reform will force the second level municipality majors to give more importance to the rural zones than the urban ones, because there, they will have the bigger and the capital of winning the elections. The political parties must be very careful in policy making and strategies because, in some cities the number of the rural zones voters is bigger that the urban zones ones and this may change the elections result.

From the economic view, the territorial reform will cause more efficiency in public grants use and will have a reduction in public budget which will be returned as public service to the citizens.

\section{References}

Bundgaard, U. \& K. Vrangbæk Reform by coincidence? Explaining the policy process of structural reform in Denmark, Scandinavian Political Studies 30, 4, 491-520, 2007.

Baldersheim, H. \& L.E Rose. Territorial choice: Rescaling Gvoernance in European states, 1-20m Baldersheim, H. \& L.E Rose (eds): Territorial choice: The politics of boundaries and borders. London: Palgrave macmillan, 2010a.

Hulst, R. \& A.V. Montfort. Inter-municipal Cooperation in Europe. Dordrecht, Springer. 2007

Ministria e Ceshtjeve Vendore, Reforma Administrative-territoriale, Raport i Pergjithshem, 2014

Ministria e Ceshtjeve te Pushtetit Vendor, Analize e Situates se Qeverisjes Vendore, 2014

Komisioni Qendror i Zgjedhjeve. www.cec.org

Studimi demografik dhe shendetesor ne Shqiperi, Instat 2011

Territorial reform in Albania, SKL International, 2012 